https://helda.helsinki.fi

\title{
Formative Interventions for Expansive Learning and Transformative Agency
}

\section{Sannino, Annalisa}

2016

Sannino , A , Engeström , Y \& Lemos , M 2016 , ' Formative Interventions for Expansive Learning and Transformative Agency ' , Journal of the Learning Sciences , vol. 25 , no. 4 , pp. 599-633 . https://doi.org/10.1080/10508406.2016.1204547

http://hdl.handle.net/10138/178032

https://doi.org/10.1080/10508406.2016.1204547

acceptedVersion

Downloaded from Helda, University of Helsinki institutional repository.

This is an electronic reprint of the original article.

This reprint may differ from the original in pagination and typographic detail.

Please cite the original version. 
Sannino, A., Engeström, Y., \& Lemos, M. (2016). Formative interventions for expansive learning and transformative agency. Journal of the Learning Sciences, 25(4), 599-633.

\title{
Formative interventions for expansive learning and transformative agency
}

\author{
Annalisa Sannino, Yrjö Engeström and Monica Lemos \\ CRADLE, University of Helsinki, Finland
}

\begin{abstract}
The article examines formative interventions as we understand them in cultural-historical activity theory, and reflects upon key differences between this intervention research tradition and design-based research as it is conceived in the learning sciences tradition. Three projects, including two Change Laboratories (CL), are analyzed with the help of conceptual lenses derived from basic epistemological principles for intervention research in activity theory. In all three interventions, learners expansively transformed the object of their activity. The CL cases, however, show that this learning process included productive deviations from the researchers' instructional intentions, leading to significant outcomes, both practical and theoretical, that were not anticipated by the interventionists. Together, these cases illustrate that an activity-theoretical formative intervention approach differs from design based research in the following ways: 1) formative interventions are based on design done by the learners; 2) the collective design effort is seen as part of an expansive learning process, including participatory analyses and implementation phases; 3 ) rather than aiming at transferable and scalable solutions, formative interventions aim at generative solutions developing over lengthy periods of time in both the researched activities and in the research community.
\end{abstract}

\section{INTRODUCTION}

Cultural-historical activity theory has from the very beginning been an activist and interventionist approach (Sannino, 2011). In recent years, the interventionist legacy and potential of this tradition has been developed by means of research programs aimed at merging practical transformation efforts and rigorous research. Each one of these research programs typically uses a specific intervention method or toolkit, such as the Organization Workshop (Carmen \& Sobrado, 2000), Clinic of Activity (Clot, 2009), or Change Laboratory (Engeström \& al., 1996; Virkkunen \& Newnham, 2013). We call these methods formative interventions (Engeström, 2011).

Intervention research in social sciences faces a persistent tension between practical relevance and rigorous analysis (Argyris, 1980; Flyvbjerg, 2001; Gutiérrez \& Penuel, 2014). In the dominant mode of intervention research, the dilemma is resolved by adhering to the standard of randomized controlled trials with predetermined end results. The problem with this approach is that the human potential to go beyond the information given to generate culturally novel solutions to social problems is only marginally explored, because the researcher-interventionists have specified the desired outcomes ahead of time. Design-based research within the learning sciences alleviates this limitation by introducing iteration and 
more holistic units of analysis into the process. However, as one of us has argued before (Engeström, 2011), the emphasis on completeness, finality and closure in much of the central literature on design-based research makes it difficult to take the agency of the learners as a foundational point of departure in this research tradition.

Ann Brown's (1992) seminal paper on design experiments was strongly motivated by the goal to "engineer innovative educational environments and simultaneously conduct experimental studies of these innovations" (p. 141). The new engineered environments would change classrooms into communities in which all participants take learning into their own hands. This was a transformational endeavor for the researcher herself, moving research on learning from the laboratory to classrooms. A similar motivation drives the writing of this article, advocating a move beyond classrooms, to discover potentials for what Engeström has referred to as expansive learning, and its core quality of transformative agency in wider communities and work settings (Engeström, 2015). Whereas Brown innovatively advocated the collaborative role of participants in design experiments, we seek to take a step further, seeing ourselves as intervening in design processes of which we cannot possibly be the engineers in control.

In formative interventions, the design is driven by historically formed contradictions (Engeström \& Sannino, 2011) in the learners' activities and is the result of their collective efforts to understand and face these contradictions and the problems they engender. The collective design effort is itself the core of an expansive learning process, involving reconceptualization and practical transformation of the object of the learners' activity. For this process to occur, the involvement of a researcher-interventionist is not essential. Collectives conduct formative interventions on themselves to address unsustainable contradictions and transform their activities - we will call such efforts intraventions. When researcher-interventionists are part of the process, their role is to intervene by provoking and supporting the process led and owned by the learners. While this may sound no different than any form of action research, a distinctive feature of formative interventions involving a researcher is the repertoire of conceptual tools developed and employed in the process, namely conceptual tools stemming from cultural-historical activity theory. When researchers intervene to provoke and support the learning process, they have specific instructional intentions. These intentions, however, are seen as only the starting point, which a truly expansive learning process typically confronts and deviates from if the learners are to produce their own collective designs. This aspect of formative interventions will be elaborated on below, specifically in the analysis of the last case we will discuss.

In this article we will focus on a formative intervention method called the Change Laboratory or CL (Engeström \& al., 1996; Virkkunen \& Newnham, 2013). The method was first implemented in 1995 in Finland. Since then it has been used in different countries in workplaces, communities and educational institutions to cope with challenging changes by means of expansive learning (Engeström, 2015). A CL intervention typically consists of six to twelve weekly sessions that last for about two hours each, with one or more subsequent follow-up sessions. In the CL sessions, participants and researcher-interventionists use a set of representational devices designed for jointly analyzing disturbances and contradictions in their activities and for developing new solutions. The conceptual tools of the CL are derived from two epistemological principles, namely the principle of double stimulation and the principle of ascending from the abstract to the concrete (Sannino, 2011). These two principles and the theoretical concepts derived from them will be discussed shortly, in the 
section devoted to our conceptual framework. It is important to highlight here, however, that successful CLs lead to outcomes that cannot be fully anticipated by the interventionist. These outcomes concern both tangible developments in the participants' activity and the conception of new methods of analysis as research outputs.

We believe that formative interventions based on activity theory can and must generate a new type of dialogue and complementarity between practical impact and rigorous analysis. We will elaborate on this relationship by examining three cases. The first case is an intravention in a school and its surrounding community. The two other cases are CL interventions, one conducted in a middle school, the other one conducted in an academic library.

Below we aim to address three key questions, to highlight the unique nature of formative interventions:

1. In which ways were the objects of the activities practically transformed in the three formative interventions?

2. What methods of data analysis were developed and employed in the two CL cases and what do these methods yield in terms of moving forward our understanding of formative interventions?

3. What kinds of indications of the generative potential of formative interventions may be identified in the two CL cases?

As background, we will present the conceptual framework that gives rise to the procedures used in the interventions, as well as to the methods of analysis employed in this paper. The first case we present was conducted primarily as an intravention by the practitioners themselves. We then present the two CL cases that involved researcher intervention. In the concluding section, we reflect upon the complementarity and differences between the three cases. We then present our answers to the three research questions above. Finally, we elaborate on key differences between formative interventions and design based research. This discussion may be read as an answer to the first question posed by O'Neill in the Introduction to this special issue.

\section{CONCEPTUAL FRAMEWORK}

Our goal in this section is to introduce key concepts that underlie the design and analysis of formative interventions. We begin by clarifying the specific activity-theoretical meaning of the terms object, expansive learning and agency, referred to but not fully explained in the introduction. These are general conceptual tools within the broad repertoire of culturalhistorical activity theory and serve as initial theoretical building blocks in this article. After that, we present the epistemological principles and key additional concepts derived from them.

The object of activity is a central concept in this framework, because different kinds of activity are distinguished by their objects. In English, the word object does not convey the crucial difference between an arbitrary thing out there and an entity at which activities are directed. A thing out there in the environment becomes the object of an activity when it meets a need and is invested with meaning and motivating power: "From this arises the 
possibility of the reversal of terms that allowed K. Lewin to speak about the motivating force of objects themselves" (Leont'ev, 1978, p. 54). In this sense, the object has drawing power and refers to something at which human efforts are directed.

"[...] The main thing that distinguishes one activity from another [...] is the difference of their objects. It is exactly the object of an activity that gives it a determined direction. [...] The object of an activity is its true motive. The motive may be either material or ideal, either present in perception or existing only in imagination or in thought." (Leont'ev, 1978, p. 62)

Due to its link to human needs, an object is a historically developing entity that is never fully attained or complete. As a general entity it resembles a vision, often utopian, which, however, finds concrete instantiations in everyday life. Human beings pursue, reproduce and potentially transform the object of their activity by means of actions on its concrete instantiations.

The object is a cultural and collective construct that has a long historical half-life. A single actor can only grasp some aspect of the object, so it is typically difficult to articulate by an individual. An object is contested and often also fragmented. Moreover, an object carries in itself the pervasive contradictions of its given socio-economic formation. In capitalism any object is at least potentially a contradictory unity of use value and exchange value. The deepseated contradictions in objects make them dynamic and unpredictable.

Expansive learning (Engeström, 2015) distinguishes itself by its focus on learning within and between activities in society at large, beyond the confines of school. Expansive learning is a creative type of learning in which learners join their forces to literally create something novel, essentially learning something that does not yet exist. It goes beyond the acquisition of well-established sets of knowledge and the participation in relatively stable practices. The metaphor of expansion depicts the multidirectional movement of learners constructing and implementing a new, wider, and more complex object for their activity. This is done with the help of mediating means employed and built throughout the design process. Expansive learning can lead to qualitative transformations both at the level of individual actions and at the level of the collective activity and its broader context. When learners pursue and grasp instantiations of the expanding object of their activity, they also construct a new motive and new long-term engagement.

Transformative agency is a quality of expansive learning. Learning expansively requires breaking away from the given frame of action and taking the initiative to transform it. The new concepts and practices generated in an expansive learning process carry future-oriented visions loaded with initiative and commitment by the learners.

Object-centered expansive learning and transformative agency are pursued through formative interventions by mobilizing procedures and analyses based on the epistemological principles of double stimulation and ascending from the abstract to the concrete. In the following, concepts central to our analysis and derived from these two principles are marked in italics. 
Double stimulation is a principle of volition and agency (Vygotsky, 1987; Sannino, 2015) that underlies the procedures and analyses of formative interventions. This principle is highlighted in Vygotsky's (1997) work on the development of children and clinical patients. It is characteristic to these studies that a task is never just the task the experimenter designed. It is always the task as interpreted and reconstructed by the subject, and cannot be strictly controlled from the outside. Rather than giving the child a task, ignoring the way she reinterprets it, and then observing how she behaves, Vygotsky and his colleagues typically also gave the child potentially useful mediating artifacts - tools or signs. The action of the child to take up and use these meditational means radically changed the nature of the task, and eventually revealed potential capabilities and emerging new psychological formations of the child.

Vygotsky (1987) used the example of a "waiting experiment" to illustrate double stimulation. In this procedure, a subject is left in a room to wait for an experiment to begin, but no one comes and nothing happens. Facing a conflict and oscillating between the urge to leave and the commitment to stay, the subject is at first paralyzed. The subject then identifies an external artifact, such as the clock on the wall, and turns it into a crucial sign: "When the hand moves to the vertical position, I will leave." After this, the execution of the action of leaving happens as if automatically. In double stimulation, the first stimulus is the problematic situation, which triggers a paralyzing conflict of motives. In trying to cope with the problem, the actors employ artifacts that serve the function of meaningful signs. These signs are second stimuli with the help of which the subjects can gain control of and transform the problematic situation.

This example highlights the fact that a conflict of motives plays a key role in double stimulation. If conflicts of motives and agency are disregarded, double stimulation is easily reduced to just another term for the general notion of mediation. Following Vygotsky, we use the notion of motive here in a broad sense, to characterize an urge, impulse or desire to follow a certain course of action or to pursue a certain object.

In CL interventions aimed at supporting expansive learning, the conflict of motives is triggered and brought into the open by presenting to the participants evidence and examples of recurring problems and disturbances in their activity as first stimuli, often in the form of videotaped critical situations and encounters. As second stimulus, the interventionists typically offer to the participants the well-known triangular model of an activity system (Engeström, 2015, p. 63). This initial second stimulus is often only a transitory analytical device, to be replaced by mediating means that the participants find or construct for themselves.

The principle of ascending from the abstract to the concrete is foundational in dialectical thinking. In activity theory, Davydov (1990; 2008), inspired by Ilyenkov (1982), turned this principle into a theory of learning and into an interventionist approach for changing school instruction. The most well-known example is Davydov's work on elementary school mathematics learning.

Key to understanding the principle of ascending to the concrete is the concept of a germ cell. The most well-known example of a germ cell is the commodity in Marx's theory of capitalism (Ilyenkov, 1982): Every commodity is a contradictory unity of use value and 
exchange value. For Davydov, the germ cell of mathematics is the real number, which is a particular case of a general relationship of quantities, where one of them is taken as a measure for computing the other. A number is obtained by the general formula $A / C=N$, in which $\mathrm{N}$ is any number, $\mathrm{A}$ is any object represented as a quantity, and $\mathrm{C}$ is any measure (Davydov, 1990). From working out and operating with this basic relationship, Davydov built a whole curriculum that resulted in a mastery of a rich and concrete diversity of mathematical phenomena and tasks (Schmittau \& Morris, 2004).

By ascending from the abstract to the concrete, a rich reconceptualization of the object of activity can be attained. This is a process that goes beyond mere observation and categorization. It consists of practical experimentation with a problematic situation, connecting it to its genetic-historical origins and abstracting from it an explanatory basic relation, also called germ cell. A germ cell abstraction is a unity of opposites. This internally contradictory unity can generate complex, theoretically mastered concrete developments. The germ cell is expansive in that it opens up rich and diverse possibilities of explanation, practical application and creative solutions (Engeström, Nummijoki \& Sannino, 2012).

Expansive learning is an application of the principle of ascending from the abstract to the concrete beyond the confines of school activities. The learning challenge typically stems from contradictions that need to be resolved by means of constructing a foundational relationship or germ cell initially not known by the instructor-interventionists themselves. The germ cell has to be discovered and modeled by the participants investigating and transforming their activity and knowledge domain (Engeström \& Sannino, 2010).

In formative interventions the researcher-interventionists offer participants theoretical and methodological resources to engage in practical experimentations that can lead to generative, novel outcomes, which we would term theoretically mastered concrete developments. Formative interventions aim at generative solutions. These are locally initiated appropriate solutions, which can lead to practical systemic transformation, as well as to the development of novel theoretical and methodological research tools. They stand in contrast to controlled experiments, which aim at generalizable standardized solutions that can be reliably reproduced.

The notion of generativity is not new in the learning sciences. In the 1970s Wittrock (1974) saw learning as a process of generating meaningful relations among concepts and between knowledge and experience. Formative interventions foster "generative reasoning" (Greeno, 1989 , p. 313) by means of constructing germ cell ideas. The learners ascend to the concrete by generating novel implementations and extensions of the germ cell.

In CL interventions, we may observe three dimensions of generativity. The first dimension is continuity and further development of the solutions created in the site of the intervention (local continuity). The second dimension is adoption and further development of the CL method in other sites and cultural contexts within the given domain of activity, for example in the domain of schooling or health care (domain appropriation). The third dimension is manifested when other interventions and research studies take into use and develop further methods of analysis initially constructed in a specific CL study (method appropriation). 
In the analysis of the three cases, we use six conceptual lenses derived from the core epistemological principles in our theoretical framework, that is, the principle of double stimulation and the principle of ascending from the abstract to the concrete. These six conceptual lenses are (1) $1^{\text {st }}$ stimulus, (2) conflict of motives, (3) $2^{\text {nd }}$ stimuli, (4) practical experimentation, (5) germ cell, and (6) theoretically mastered concrete developments. The analysis performed with the help of these six conceptual lenses aims at answering our first research question: how the object of activity is formed. This may be also read as an answer to the second question posed by O'Neill in the Introduction to this special issue.

The six conceptual lenses are obviously intertwined, and cannot be presented in a mechanical order without distorting the dynamics of the actual intervention. Thus, in the analysis of each case, some of the six concepts may appear more than once. For example, practical experimentation may appear both in the search for a second stimulus and in the formulation and examination of a germ cell.

In addition to the six conceptual lenses, we analyze the two CL cases in order to answer our second and third research questions: What methodological developments took place and what indications of generativity can be identified. Our analysis of the methodological developments may be read as an answer to O'Neill's third question in the Introduction to the special issue. We will examine possible indications of generativity by focusing on the three dimensions presented above: local continuity, domain appropriation, and method appropriation. The examination of generativity may also be read as a partial answer to question four by O’Neill about unintended consequences of interventions.

\section{CASE 1: INTRAVENTION IN A FAVELA SCHOOL}

Our first case concerns a change initiative undertaken in a school located in a favela, a shantytown in south São Paulo, Brazil. The problem that served as the impetus for this initiative was the repeated flooding of a polluted river that runs between the school and the neighborhood. Part of the garbage produced in the community has ended up in the river. When it rains, the river floods and invades much of the neighborhood. Many people have no other option but to cross the flooded river in order to reach their homes or to save their belongings. The flood brings diseases and pests with it and directly affects the school.

In this case, the wellbeing of the community became the object of change efforts and expansive learning. The trash is a concrete instantiation of the evolving object of the school's activity. Trash has become a commodity in a literal sense worldwide (Lehman, 1999). The use value of trash for the inhabitants is that its removal, prevention and eventual recycling will improve the quality of the community's life. Its exchange value is exhibited in the neglect and avoidance of costs associated with the improvement of the environment in the neighborhood, and potentially in the opportunity to turn trash into lucrative business. In this case, dealing with the consequences of the flood expanded into a long-term engagement with improving the living conditions and health of the community.

The transformation efforts in the favela are an example of an intravention because they took place on the initiative of local actors. In this case the process was initiated and led by two pedagogical coordinators of the school who had participated in a training program aimed at 
reconceptualizing school management in São Paulo (Liberali, 2012). There was no direct involvement of a researcher-interventionist coming from the outside. Rather, after the local initiative by the two coordinators had been under way for some time, the third author of this article began to observe and document the local change effort without acting as an interventionist.

The data consist of documents produced by the participants, interviews, and observation periods on site, supported by photographs and video recordings. The initial analysis was conducted in a temporal and narrative mode, by constructing a thick description of the events and participants' reflections on them along a timeline. In this paper, the initial narrative is interpreted and condensed through the conceptual lenses introduced in our conceptual framework.

Seen in terms of the principle of double stimulation, the flood and its consequences were the first stimulus, posing a serious problem and threat to the population and school. Prompted by training sessions on new tools for school management, the lead local pedagogical coordinator explicitly voiced a pressing conflict of motives she and the school as a whole were experiencing between implementing the curriculum and engaging with the urgent challenge of the flood. In the same context the coordinators constructed a new educational management plan that served as a second stimulus to find a way out. With the help of the management plan, the lead coordinator explicated a need to transform the object of the activity of teaching-learning: "if teaching-learning does not make my life better, as a person, as a human being or as pedagogical coordinator, it has no meaning," and "at the moment that the school wants to transform reality it transforms people who have an 'accept anything' mindset." In her emerging vision, the object of the school would no more be abstract curricular contents; it would be making local people's lives better by transforming their reality and their mindset.

Practical experimentations in line with the principle of ascending from the abstract to the concrete were initiated in line with the new management plan. These included organizing a student relay race on the flood site, meetings in the neighborhood health care center, debates on how the community could deal with trash, and a symbolic hug between teachers, health professionals and community inhabitants. The school also produced a film and organized a movie session inviting the community to watch themselves in an improvised theater in the same street where the river overflows. In the school, the teachers worked with the river issue in classrooms connecting it with the curricula of their different subjects. Eventually the experimentations led to a manifesto titled My Stream, My Life, compiled by the leading pedagogical coordinator from materials produced during these events with the community. This manifesto became the germ cell for sustained and expanding transformation efforts. A passage from the manifesto reads as follows:

As much as they (authorities) want to convince us with frequent neglect, abandon, injustice and discard, that we are nothing, that we are nothing else than a dead and polluted stream that is in the city board, a place where governors deposit all their trash of forgetfulness, if they think we deserve this trash, it is time that the biggest metropolis of southern hemisphere learns with schools that trash becomes art, learns with the Samba School Go Ahead that trash becomes luxury, learns with the health care center that trash can provide union among everybody, learns with community neighbors that trash is life. 
The manifesto as a germ cell captures the essence of a new, emerging object. The passage from the manifesto and the paradoxical expression "trash is life" convey the generative expansive potential of practical experimentations through which an entire community became aware of its own rights and acquired confidence that it can make a difference. The manifesto gave continuity and meaning to numerous further efforts by the community to improve its life.

Ascending to the concrete is still happening in this community. The community received a human rights prize from the city of São Paulo for their efforts with the flood problem. School and community leaders collected signatures in a petition demanding the construction of a park by the river. After more than 2000 signatures were delivered, one of the community leaders became the representative of the region's security councilor with closer relations to politicians. In 2013 the community representatives practically invaded a meeting of the Regional Council of Environment, Sustainable Development and Peace Culture to present their demands. As a consequence, the mayor sent machines to clean up the river twice a year. The community has managed to get more lighting during the night in the favela. There is now an ambulance closer to the community, so people can call and have prompt service. Community members handle garbage in a better way, avoiding throwing it into the river. In 2014 the councilman representing south São Paulo visited the school and started developing a project with students and the community to address the problem of the flood and other pressing issues in the community.

In what sense was this a formative intervention? Formative interventions, including intraventions, aim at transforming the participants' vital collective activities. As this case shows, the key principles of formative interventions may be found operating in many interventions not designed as CLs or other specific intervention methods based on activity theory. Interventions happen when people try to transform activities - their own or others' in some deliberate and systematic ways.

\section{CASE 2: A CHANGE LABORATORY IN A MIDDLE SCHOOL}

\section{The intervention}

In the fall of 1998, a research group ${ }^{2}$ conducted an eleven-week CL intervention with the teachers of a middle school, located in Jakomäki, a disadvantaged area of Helsinki, Finland. In 1997, the unemployment rate of Jakomäki was $25 \%$, compared to $15 \%$ in the city as a whole. Only $5 \%$ of the adult population of Jakomäki had higher education, compared to $21 \%$ in Helsinki as a whole. In 1998, the Jakomäki school had about 280 students. About 30\% of them were recent immigrants and refugees, mainly from Russia and Somalia. The school employed 27 full-time teachers, including the principal, who formed a motivated and selfconfident group, willing to face new challenges and develop their school. All the teachers participated regularly in the CL sessions and in the different change efforts it spawned.

\footnotetext{
${ }^{2}$ The research group consisted of Yrjö Engeström (PI), Ritva Engeström, Pirjo Korvela and Arja Suntio.
} 
In weekly two-hour sessions, with the help of conceptual tools from activity theory, the teachers discussed and analyzed videotaped problem situations and accounts from their daily experiences. By putting the problems in a historical perspective, they identified present developmental challenges in the activity of the school. On this basis, the teachers constructed a vision for the school's future and designed six sets of practical changes as immediate steps toward their vision. The teachers implemented the changes during the winter and spring of 1999 , and continued to do so in the school year 1999/2000. ${ }^{3}$

The research team videotaped all the CL sessions. It also videotaped classroom lessons and interviewed teachers, students, and parents. The team continued to follow and document the implementation efforts for over 18 months. We will focus on what we find the most consequential one of the six change efforts, namely the design and implementation of a Final Project for $9^{\text {th }}$ grade students who were about to finish their middle school. We will particularly examine the impact of this innovation on the transformation of the object of the teachers' work activity - the students and their learning.

Before the CL sessions, members of the research group spent about two months collecting ethnographic data in the school. Samples from these data, mainly in the form of recorded interviews and videotaped interactions inside and outside classrooms, were selected and presented to the participants as first stimuli in the early sessions of the intervention. For example, the researchers noticed that the students spent their recesses sitting on the floors of the school corridors. This seemed somewhat bizarre, so the researchers asked the students why they did this. The answer was: "Because there is nothing else to do." When a videoclip was shown in the CL session of students sitting on the floor, the teachers' immediate reaction was that this was an example of the students' apathy. The first stimuli presented to the teachers repeatedly elicited characterizations of students as apathetic. The teachers' discourse on student apathy continued throughout the intervention. However, the teachers subsequently also brought up an opposite image of students as energetic and active. The paradox was that apathetic students are relatively easy to control, but active and energetic students may pose a risk. Many participants experienced and expressed this as a conflict of motives: Should students be trusted or controlled?

The researcher-interventionists invited the participants to analyze the historical roots of their current troubles and to model different developmental phases of the school. This was done by dividing the teachers in groups according to the decade in which they started working at the school: the 70s group, the 80s group, the 90s group, and the newcomers' group. Each group worked out a description of the schoolwork and its contradictions in the respective decade. In these accounts, the emergence of student apathy was connected to socioeconomic changes in the community.

The next step in the CL was the envisioning of the future model of the activity. Each one of the teachers was asked to take home a copy of the general model of an activity system (Engeström, 2015, p. 63) and to fill the template with features that would describe the teacher's vision of how the school should function in the future. On the basis of their

\footnotetext{
${ }^{3}$ Finnish schools and teachers have a large degree of autonomy with regard to planning their curricula and instruction. This is often seen as one of the main strengths of the Finnish school system (World Bank, 2012).
} 
contents, the researchers sorted and integrated the 27 individual visions into three, temporally ordered, collective visions: short-term, middle-range, and long-term. The shortterm vision focused on increasing and improving the existing means and resources of schoolwork. The middle-range vision focused on learning-centered pedagogy and "learning to learn." The long-term vision focused on networking and connecting instruction with the world outside the school. In the discussion the teachers found this way of dividing up and defining their visions appropriate and, more importantly, concluded that instead of competing or being mutually exclusive, the three could be seen as complementary successive phases. This three-phase vision functioned as the second stimulus in the intervention. In itself the three-phase vision was not a solution to the conflict of motives; it was an instrument with the help of which a concrete solution could be constructed.

In the seventh session of the CL, the teachers selected concrete issues for their immediate change efforts. A taskforce group of interested teachers took responsibility for each of the six issues. Practical experimentation with short-term improvements in the school was initiated. For example, to change the apathy-generating surroundings into an environment more respectful and supportive of students' initiatives and interests, a set of sofas was placed in the entrance hall of the school, as well as benches and computers in the corridors. As we see it, these practical experimentations paved way for the formulation and implementation of the Final Project as germ cell. It soon became clear that, among the issues selected as foci of practical experimentation, the Final Project was the most ambitious spearhead of change. It involved all the teachers and was also enthusiastically accepted by an assembly of students' representatives. The Final Project taskforce discussed the relationship between the vision (second stimulus) and the emerging germ cell innovation, and it is noteworthy that the participants defined the Final Project as a change that represented the middle-range vision, not merely the short-term improvements.

The task force and eventually all the teachers quickly agreed on the basic idea of the Final Project. The graduating $9^{\text {th }}$ grade students in the then-current process used to leave the school with only a report card and grades in their pocket. The teachers felt that the students should leave with something more tangible, with an achievement they could be proud of. The Final Project was to be a cross-subject project on any relevant topic chosen by the student. The Final Project was to be completed during the winter/spring semester of the last school year, and a number of school hours were set aside exclusively for working on it. A teacher was to be assigned to guide and supervise each student's Final Project. The supervising teacher might or might not be a teacher responsible for teaching the particular school subject closest to the topic of the project. If the student wished, he or she could ask the Final Project to be evaluated as grounds for raising the student's final grade in a school subject. The outcomes of the Final Projects were to be displayed in an exhibition at the end of the school year.

The Final Project attempted to go beyond deep-seated constraints in school instruction. It allowed the students and required the teachers to operate beyond and across the encapsulated school subjects. It allowed the students and required the teachers to work on a long-term basis, preparing Final Projects over a whole semester, thus going beyond the temporal punctuation of lessons and tests. Perhaps most importantly, the Final Project introduced work motivated by the pride of achieving something beyond the obligatory demands of the curriculum. But instead of dichotomously separating this opportunity from grades, the Final Project offered the students a chance to take their work-of-pride and use it to enhance their grades, too. Thus, the Final Project made visible and problematized the contradictory 
character of grades, both for the students and the teachers. From this point of view, the Final Project may be seen as a germ cell - a small but potentially expansive change capsule.

As the plan for the Final Project was discussed in the last session of the CL, an important productive deviation occurred, taking the project beyond the plan designed by the teachers and endorsed by the interventionists. The plan had just been presented to a visiting representative of the city's board of education when a debate emerged concerning the inclusion of immigrant students in the Final Project. The teachers responsible for planning the implementation had excluded the immigrant students from their plan because most immigrant students were studying in special classes and, in spite of their age, were not able to formally complete the academic requirements of the Finnish middle school. This school had separate classes for immigrant students who had recently moved to Finland and did not know enough, or any, Finnish. These immigrant students' classes were temporary classes where they were taught either in their native language, or in both Finnish and in their native language. The immigrant students' teachers were strongly in favor of involving their students in the Final Project and argued this positive orientation with the help of insights from their own current and prior experiences of working with them.

As a result of this discussion, the initiative of the immigrant students' teachers was accepted and the Final Project was implemented with all students. In the spring of $1999,71 \%$ of the $9^{\text {th }}$ graders completed their Final Projects. Of those who completed them, 54\% used their Final Projects successfully to raise some of their grades. In $2000,91 \%$ of the $9^{\text {th }}$ graders completed their Final Projects, and $65 \%$ of them successfully used the project to raise their grades. The topics of the projects ranged from Einstein's theory of relativity and Picasso's cubism to Michael Jackson, the four-channel amplifier, graffiti, and a child's pajamas. This rich diversity indicates that the abstract idea of the Final Project was becoming a lived reality, that is, a theoretically mastered concrete was emerging. The immigrant students successfully completed the Final Project. In one of the follow-up meetings, organized in August 1999 to assess how the innovations were introduced in the teaching practices and what results had been obtained, one of the immigrant students' teachers stated:

Teacher 6: As I teach the immigrant kids' class, pretty much everybody, I think eight or seven out of ten students, did complete the Final Project. I was myself surprised by how fine they actually realized that. They all did it during the textile work lessons and then also used other class hours to complete it. But anyway they actually completed them, and how fine they came out!

The students of this particular teacher were predominantly Somali girls whose literacy skills were very limited even in their own native language. However, ascending to the concrete goes beyond the practical implementations of the Final Project. When implemented, this germ cell had the potential to change the way in which the teachers constructed their object, the students.

\section{Analysis of the intervention}

When teachers talk about their students, they talk about and categorize the object of their work. A major research goal of the analysis of the Jakomaki case was to discover changes in the overall profile of the categories that the teachers used to evaluate students, the object of their activity (Engeström, Engeström \& Suntio, 2002a). This goal required that the analytical 
procedure focus on changes that occur over time in very basic, typically dichotomous categorizations. For this a method called longitudinal categorization analysis was developed. Related to ethnomethodological membership categorization analysis (Hester \& Eglin, 1997; Lepper, 2000; Stokoe, 2012), longitudinal categorization analysis is aimed at identifying durable sea changes in a community rather than minute short-term variations in individuals or small groups.

In schools, the most salient categories in teachers' talk about students are related to negative and positive, or pessimistic and optimistic, characterizations of students' competence and potential. The importance of these categories has been amply established in research and debate on teacher expectancy (Rosenthal \& Jacobson, 1968; Jussim \& Harber, 2005). Negative talk about students may be seen as expression of deficit-oriented educational discourse (Gorski, 2011; Valencia, 2012), whereas positive talk may be seen as expression of asset-based views in education (Lindsey, Karns \& Myatt, 2010). Focusing on conversation data, Horn (2007) analyzed the ways teachers categorize students in different teaching practices, tracing relationships between teachers' talk and reform discourses.

Typical negative categorizations in the Jakomäki data were related to students' expected lack of interest, effort and stamina in demanding tasks.

Teacher 12: Half of the students will give up the whole idea. I have given them a task to prepare a presentation, one tenth-grader has done it, the others have slipped away. This is what they will always do.

Correspondingly, positive categorizations were focused on students' diligent efforts, accomplishments, capabilities and potentials, often expressed in a tone of surprised delight.

Teacher 7: One notices, after giving them feedback, that they are actually glowing, they know they have worked, and then they receive a good evaluation for it.

In order to isolate statements corresponding to such categories, transcriptions of the teachers' recorded conversations in 11 discussion sessions were coded into 256 topical sequences, out of which 161 were focused on students. These 161 sequences were further coded as either positive or negative. The coding was done independently by members of the CL research team. Disagreements among coders were collectively discussed and resolved with the help of researchers not involved in the intervention. For member checking (Lincoln \& Guba, 1985), the results of the analysis and representative data examples were subsequently discussed with the teachers.

This kind of analysis yields a picture of what happened after a CL intervention in the basic orientation of a working community. The Jakomäki CL intervention itself ended in December 1998, but the data covers teachers' discussions until October 1999. This lengthy follow-up makes the findings more robust. Such findings pertain primarily to the generative potential of a CL rather than the internal dynamics of the intervention process. If key categorization patterns do not significantly change after a CL, we may question whether, or to what extent, expansive learning was actually achieved. 
The teachers' statements concerning the students were categorized as predominantly negative or predominantly positive. From an activity-theoretical point of view, qualitative changes in the contents and categories of the teachers' talk are of great importance, because they allow tracing the extent to which the theachers are reconceptualizing the object of their activity throughout and after the CL. The 11-month period of data collection was divided into seven phases. The analysis shows a progressive shift toward a predominantly positive talk about the students (Figure 1). The shift did not happen abruptly. It took place as gradual emergence and increase of positive talk, reaching its high points when the Final Project was implemented and then individually and collectively evaluated.

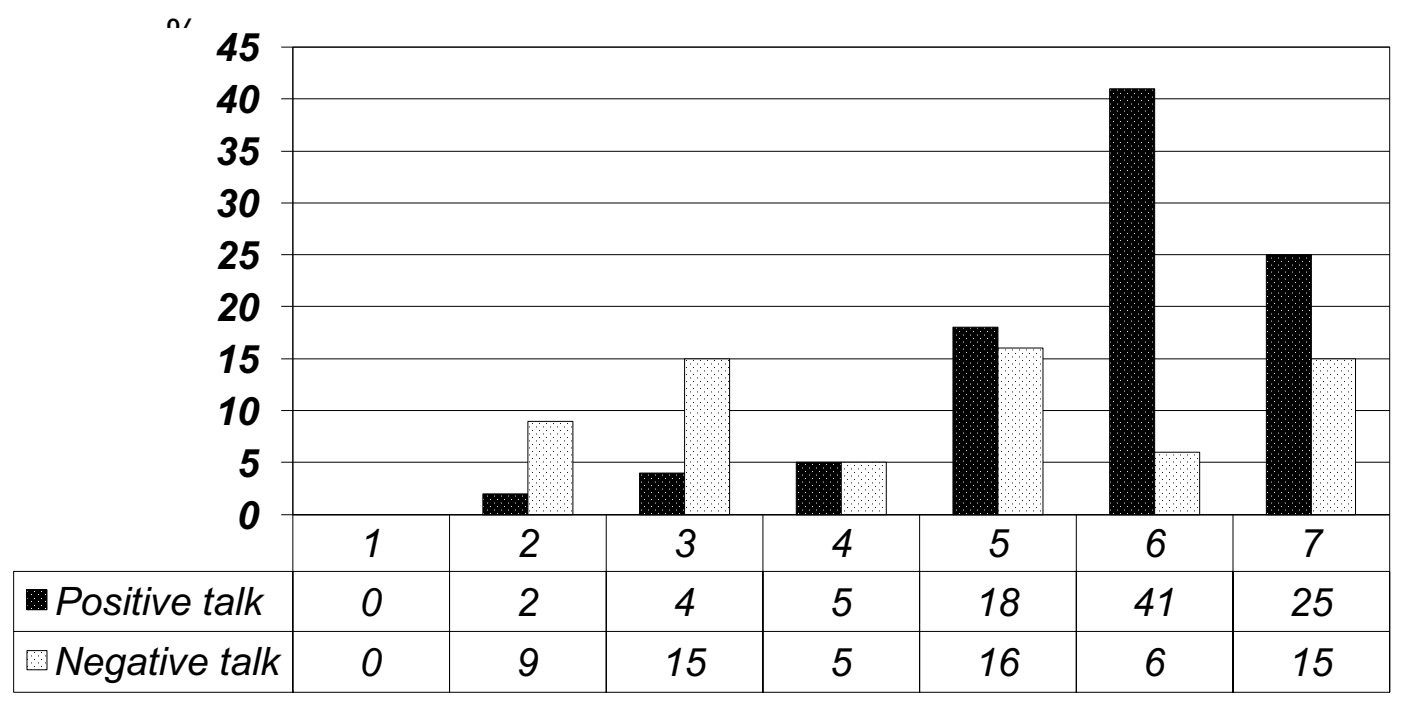

Figure 1. Percentages of predominantly positive and predominantly negative topical sequences of teachers' talk about students in the seven phases of the Final Project process (total number of all topical sequences in a given phase is $100 \%$ )

Importantly, negative talk did not disappear. In other words, the emergence of positive talk about students was truly an expansion and enrichment of the repertoire; it did not emerge at the cost of previous ways of talking. The analysis further examined this phenomenon of expansion as enrichment by looking in detail into the contents of the teachers' talk about students in the planning and evaluation phases of the process. In the planning, teachers' talk was limited to a range of seven substantively different topics; in the evaluation phases the teachers covered 16 substantively different topics. Again, the early topics did not disappear, but the range was radically widened. It is not an accident that the teachers' positive talk about students gained momentum only during the practical implementation of the Final Project. It seems that while the expansive transformation of the object was manifested in the teachers' talk as redefining the students as competent and energetic, this transformastion was triggered by and grounded in the practical actions and material artifacts of the Final Project.

\section{Generativity}

Indications of generativity in the CL intervention at Jakomäki middle school may be observed following the three dimensions presented in our theoretical framework: local continuity, domain appropriation, and method appropriation. Local continuity was manifested in the decision of the teachers to engage in a second round of CL intervention in 2000-2001. This second CL was focused on creating new ways of learning and instruction in cross-subject thematic units utilizing information and communication technology 
(Engeström, Engeström \& Suntio, 2002b). Domain appropriation is evident in the fact that after the Jakomäki interventions, CLs in school settings have been conducted at least in Italy (Sannino, 2010b), Finland (Virkkunen \& Tenhunen, 2010; Teräs \& Lasonen, 2013), Botswana (Virkkunen, Nleya, Newnham \& Engeström, 2012), United Kingdom (Naghieh, Thompson \& Montgomery, 2014), and Russia (Lapshin, Ivanova \& Chernish, 2015). Several of these interventions have been wholly or partly initiated by school principals and teachers.

Method appropriation may be observed as well. The methodological insight of tracing the evolution of negative and positive categorizations of students has been further pursued and developed by Sannino (2010a), Virkkunen, Nleya, Newnham and Engeström (2012), and Rainio and Hoffman (2015). In these cases, the intervention and data analysis not only made visible the negative categorizations and their problematic consequences; the studies seem to indicate that participants also began to question and break out of the vicious circles of restrictive categorization, moving toward instructional practices that build on an optimistic construction of students as capable learners. Sannino's (2008) analysis of such breaking-out actions in the Jakomäki school intervention led to the first typification of expressions of transformative agency, which was subsequently elaborated into a method of analysis of formative intervention processes in its own right (Haapasaari, Engeström \& Kerosuo, 2014; Vänninen, Querol \& Engeström, 2015).

\section{CASE 3: A CHANGE LABORATORY IN AN ACADEMIC LIBRARY}

\section{The intervention}

In the fall of 2010, a CRADLE research team ${ }^{4}$ conducted a CL in the City Center Library of University of Helsinki. The CL consisted of eight videotaped sessions, followed some months later by two follow-up sessions with the library staff, their management, and representatives of four pilot clients, namely four university research groups in social sciences and humanities.

The Helsinki University Library was undergoing a major transformation in at least three respects. First of all, the digitization of information and the emergence of powerful webbased tools of information storing and searching have led to a radical decrease in researchers' physical visits to the library, and also in their use of physical books and journals. Secondly, especially in the city center campus of the university with social sciences and humanities collections, numerous small discipline- and department-based libraries were being physically and administratively merged into a large unified campus library. Thirdly, the university was constructing a new building for the City Center Campus Library. The concern was that the new library facilities might be actively used only by students, while researchers and faculty would only use web-based digital services.

The researchers' working hypothesis was that research groups do in fact need new kinds of library services to master large and complex sets of data as well as the demands of information search, electronic publishing, evaluation of one's own research, and visibility in the scientific community. Preparatory analyses of the intervention team led it to assume that

\footnotetext{
${ }^{4}$ The research group consisted of Yrjö Engeström (PI), Heli Kaatrakoski, Anne Laitinen, Heli Myllys, and Juhana Rantavuori.
} 
the present object of the library's work with researchers was an individual researcher's discrete request for publications or publication-related information. The new object would be a long-term partnership with a research group needing support in the management of data, publishing, and following the global flow of publications. This new object would require a new division of labor, new competences, and a new organization model for the library. Not all services that would meet these emerging needs were yet there. They needed to be coconstructed and continuously reconfigured in flexible knotworking (Engeström, Engeström \& Vähäaho, 1999) between librarians and research groups: "The notion of knot refers to rapidly pulsating, distributed and partially improvised orchestration of collaborative performance between otherwise loosely connected actors and activity systems" (Engeström, Engeström \& Vähäaho, 1999, p. 346). The CL intervention was conducted to create groundwork for such knotworking in the form of a jointly constructed service palette for research groups, as well as corresponding new work practices and organizational structures.

The first session of the intervention was held with the library staff only, and the second session with both the library staff and four pilot research groups - Cognitive Science, Communication Law, Finnish Language, and Gender Studies. The third session was held with the library staff and the first two pilot research groups, and the fourth session with library staff and the two remaining pilot research groups. The participation pattern of sessions 3 and 4 was repeated in sessions 5 and 6 . The final seventh and eighth sessions as well as the follow-up sessions were held with the library staff only.

The team used videotaped interview clips as first stimuli in the intervention. In the clips, librarians took up their worries about specialization and the perceived pressing demand to become experts in specific domains of science. This triggered the voicing among the participants of a conflict between the motive of being a generalist librarian and the motive of being a competent substance expert in a given domain of science. This conflict was directly related to the contradiction between the emerging object of researchers' new needs in the globally networked world of digital publishing and the traditional division of labor within the academic library. Both the researchers' new needs and the available arrangements of division of labor were relatively poorly charted and minimally debated when the CL started.

In the two first sessions of the CL, the participants analyzed the historical development of the services of their library and the current needs of researchers for new kinds of library services. The results of this analysis were summarized in the form of a tentative service palette to be discussed and redesigned with representatives of research groups in the subsequent CL sessions. In this case, practical experimentation was initiated in discussions with representatives of the clients (research groups) in intervention sessions 2 to 6 . The Cognitive Science research group got most actively engaged in joint experimentation with the librarians. Early on, it became evident that the research group needed help to systematize its ways of handling, storing and archiving data.

A small group of library professionals and Cognitive Science researchers started to develop solutions for the data management problems. In the fifth session, the library staff presented their ideas about what they now called a quick reference guide for data management. This term was used to denote a collection of guidelines to be used at different stages of the research to store data systematically and to do away with random data descriptions used by numerous individual researchers. The library explained that the purpose of the guide was to 
enable data to be stored safely in a structured way. The researchers welcomed this type of assistance and a meeting was organized outside of the CL sessions to discuss the details of the quick reference guide. The guide was eventually created and put into use. This kind of practical experimentation with the object, in this case the clients and the services, opened the librarians' eyes to the needs and potentials of their clients and thus paved way to the formulation of the second stimulus and germ cell.

In the CL sessions, the librarians initially used unilaterally authoritative and instructional modes of interaction: the library workers would present some possible new services, the researchers would listen and passively accept the ideas. However, this script was challenged and broken by the clients. In the third session of the CL, for instance, the library professionals presented to the researchers a new service called FeedNavigator. This is a webbased service developed to enable researchers to follow and obtain new articles immediately upon release according to their personal preferences and keyword profiles. When this service was introduced in the CL session, a representative of the Cognitive Science research group challenged the librarians by saying "I already have this kind of a service in use." The episode brought to surface a further conflict of motives: the motive of continuing with the usual oneway instructional mode of relating to clients $v s$. the motive of taking the clients' work as a starting point and possibility to collaboratively develop something new.

The researcher-interventionists suggested knotworking (Engeström, Engeström \& Vähäaho, 1999) as a preliminary characterization of the new type of work needed in the library. In knotworking, services would be co-constructed and continuously reconfigured in flexibly changing collaborative formations or partnerships between librarians and research groups. Knotworking seemed like an idea that could generate answers to both the specialization $v s$. general expertise conflict and the instruction $v s$. collaborative development conflict. Key managers and staff members of the library quickly adopted the idea of knotworking as a second stimulus for the change effort. Besides a brief introduction to the idea at the beginning of the CL process, the researcher-interventionists did not attempt to define or fix the contents of the notion. Yet the notion started to take on a life of its own in the discussions of the participants. A prior analysis (Engeström, 2013) shows an interesting increase of the frequencies of the use of the terms "knot" and "knotworking" starting halfway through the $\mathrm{CL}$ and culminating in the last two sessions of the intervention.

In the early sessions these terms were practically exclusively used to refer to collaboration with clients, the research groups. But starting in the sixth session, the term began to be increasingly used to actually envision the way the librarians wanted to learn to work and interact within the library and across the boundaries of the different university campus libraries. This shift was something the interventionists did not expect or plan. In the last two CL sessions, the participants constructed a new organization chart to be implemented in order to facilitate knotworking both among staff across campus libraries and between staff and research groups. This new organization chart may be seen as a materialization of the second stimulus. As the notion of knotworking was appropriated and transformed to meet the needs of the practitioners, it became the germ cell idea for the new way the participants wanted to organize library work. We might say that in this case, the second stimulus and the emerging germ cell were partly merged. The notion of knot took shape as a tension-laden unity of turning inward to pool and combine the competences of staff in flexible ways - and turning outward to manage partnerships with research groups. 
Steps toward theoretically mastered concrete were reported in the follow-up sessions of the intervention. A librarian told about collaboration between practitioners from two campus libraries to create a web-based service for researchers to generate data management plans. When the researcher-interventionist asked who the leader of the editorial team was, the librarian laughed and replied "I don't know if we actually have a leader." She continued by explaining:

Librarian 4: We have these different levels, the level of the whole university library and the campus level. Sometimes this causes rigidity. So we thought that we will make a somewhat unofficial, grassroots level [...] Actually we put together a knot here, around this problem. We thought that if we get something very official, it will not make progress, and we wanted it to go forward.

The library director expanded on the librarian's account:

Library director: [...] We wouldn't demand anymore a hierarchical administrative approach always when there is a new problem to solve [...] Instead, we have clear development responsibilities and within those people have the possibility to quite freely form such knotlike small groups across the responsibility boundaries. We aim at a certain kind of selforganizing capability.

When the notion of knotworking was first introduced to the librarians, it was just an abstract idea. Later on the practitioners appropriated the idea as a second stimulus and germ cell that served their own practical agentive design efforts. One might say that a somewhat idealistic notion of knotworking was expanded downward, so that it got its feet on the ground. The elusive, skeletal name began to acquire flesh and blood around it.

\section{Analysis of the intervention}

A primary research goal of the analysis of the library case was to gain a firmer understanding of the dynamics of expansive learning that occurs in the CL. The data consisted of transcripts of the videotaped discussions in the eight CL sessions. The sessions included altogether 4184 speaking turns. The analysis focused on the learning actions taken in the sessions (Engeström, Rantavuori \& Kerosuo, 2013). For this, a specific method was developed, called analysis of expansive learning actions and deviations from instructional intentions.

The method has its roots in Davydov's work on the learning actions involved in the process of ascending from the abstract to the concrete (Davydov, 2008). As a further elaboration of this framework, the method used for analyzing the library CL operated with a typology of seven expansive learning actions (Engeström \& Sannino, 2010): (1) Questioning, criticizing or rejecting some aspects of accepted practices and existing wisdom; (2) Analyzing problematic situations by tracing their origins and evolution (genetic-historical analysis) or by constructing a representation of the inner systemic relations of the activity (actualempirical analysis); (3) Modeling the newly found explanatory relationship in some publicly observable and transmittable medium; (4) Examining the model in practical experimentations aimed at fully grasping its dynamics, potentials and limitations; (5) Implementing the model by means of practical applications, enrichments, and conceptual extensions; (6) Reflecting on and evaluating the process; (7) Consolidating the outcomes 
toward a new stable activity. These learning actions also serve as a general model for the interventionists' instructional intentions in a CL.

An expansive learning action was identified by (a) isolating topical conversational episodes, (b) for each episode, formulating a preliminary description of the learning actions performed in one of multiple turns of talk, (c) returning to the episodes and the overall conversation to specify the epistemic function of each learning action. The epistemic function was determined using the framework of the seven expansive learning actions presented above. As the seven expansive learning actions are steps in the process of ascending from the abstract to the concrete, recurring smaller cycles or iterative loops were identified within the intervention.

By examining the contents and epistemic functions of the actions that were not coded as expansive, the method allowed the analysts to identify also non-expansive learning actions. This step of the method is in line with Maxwell's (2005, p. 112) point that "identifying and analyzing discrepant data and negative cases is a key part of the logic of validity testing in qualitative research." The non-expansive actions were named descriptively, on the basis of their contents, without aiming at a theoretically systematic categorization.

Finally, to identify the deviations, it was necessary to specify the instructional intentions of the researcher-interventionists. For this, the written plans of the interventionists as well as recordings of the planning discussions of the interventionist group were used. On this basis, the intended function of each CL session was named in terms of the planned dominant expansive learning action and this intention was used as point of comparison when examining what actually took place.

To accomplish dependability (Lincoln \& Guba, 1985), the analysis was conducted iteratively and collectively. The focus was particularly on the coding of boundary cases in which the learning action was difficult to categorize. All such actions were identified and negotiated in the CL research group until a consensus was reached.

This analysis yields a picture of the dynamics of learning with the CL intervention. It reveals to what extent the seven expansive learning actions were actually taken in the process, to what extent they formed cyclic patterns, and to what extent deviations from instructional intentions took place. If a CL intervention is found to contain only some of the seven expansive learning actions, if these actions do not form cyclical patterns, and if there are no significant agentive deviations from the interventionists' instructional intentions, we may question whether, or to what extent, expansive learning was actually achieved. This can serve as basis for comparisons between different CLs that may eventually lead to the identification of different typical profiles of expansive learning in formative interventions. The tracing of deviations from instructional intentions with this type of analysis also makes it possible to locate phases in which the learners agentively take charge of the process and redirect the course of learning.

The analysis of the CL transcripts shows that six of the seven expansive learning actions occurred in the data, the most frequent ones being the action of analyzing the situation and the action of modeling, followed by the action of examining the new model and the action of 
questioning (Figure 2). The actions of implementing the new model and reflecting on the process were the least frequent ones, and the action of consolidating and generalizing did not occur in the data. In terms of the overall effort, this CL was evidently more focused on questioning and analyzing the situation, modeling a new solution, and examining the model than on implementing the model and reflecting on the process. The relatively infrequent occurrence of actions of implementing and reflecting on the process, as well as the absence of actions of consolidation and generalization, may be to a large extent due to fact that the analysis did not include the follow-up sessions that took place several months later.

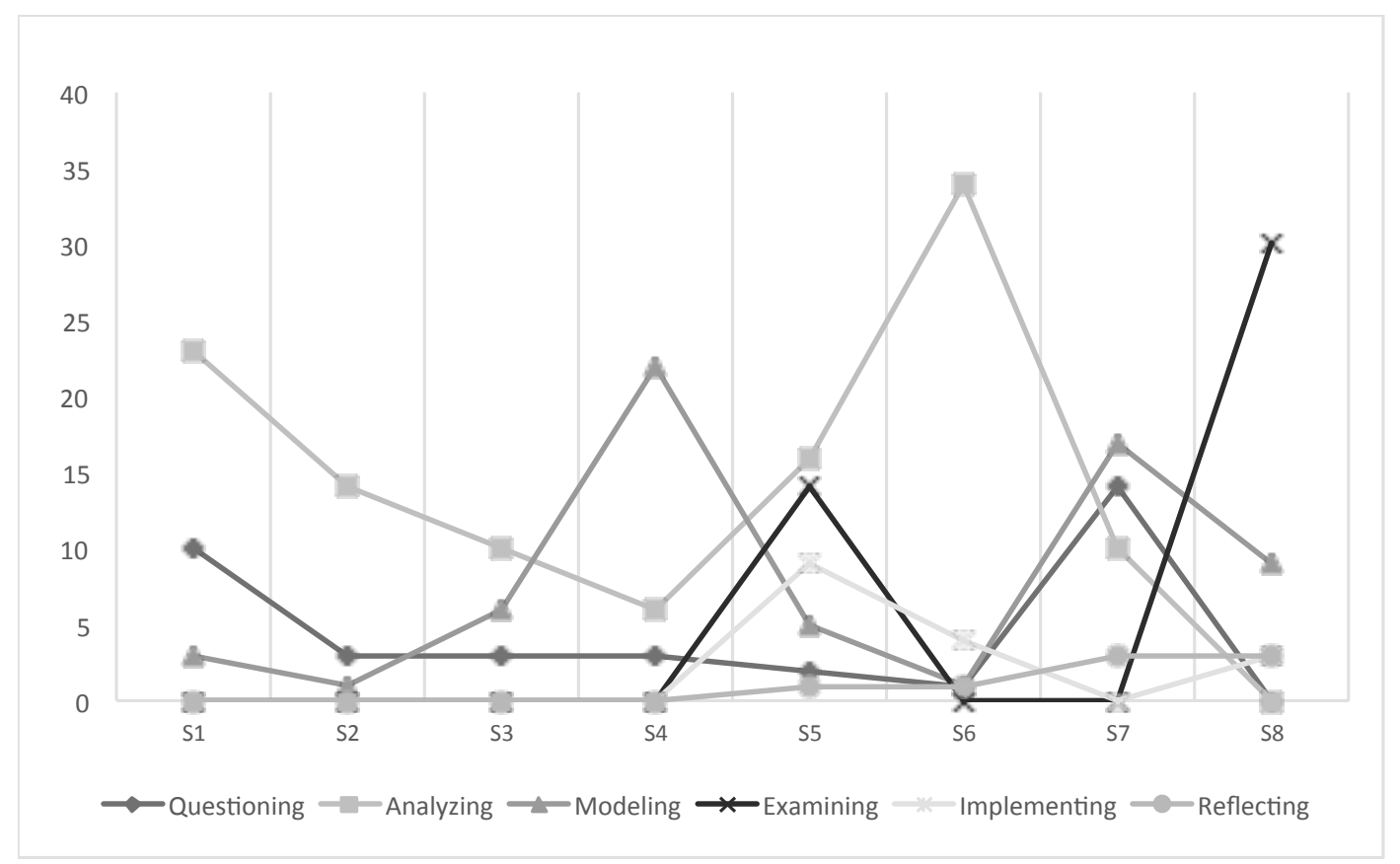

Legend: $\mathrm{S}=\mathrm{CL}$ session

Figure 2. Evolution of frequencies of different expansive learning actions over the course of the CL sessions

In the light of these findings, expansive learning emerges as a process interspersed with frequent non-expansive actions, some supportive, some neutral, some digressing, some also adverse to expansion. If in theory and in previous studies expansive learning has often been depicted as a relatively pure process, these findings depict it as a path emerging within a texture of various bypaths, or as a melody taking shape among background sounds and complementary, perhaps also competing tunes.

The first two CL sessions were dominated by questioning and analyzing. In the third and fourth sessions, the actions of modeling became dominant, along with analyzing. In the fifth and sixth session, the models were examined and their implications were analyzed, and the actions of implementing showed up for the first time. So far, the pattern was largely in line with the general sequence of ascending from the abstract to the concrete. However, the shift toward implementing did not continue. Instead, something unusual happened in the seventh session. The actions of questioning and modeling jumped up and intensified again. In the eighth session, modeling remained fairly intensive, and examining the model jumped up to a very intensive level. The questioning, modeling and examining actions were done with great 
intensity in the last two sessions, more so than in the earlier sessions. It seems that there was an iterative loop within the expansive learning process. This iterative loop is clearly a deviation from the interventionists' instructional intentions.

Two types of deviations from instructional intentions were identified, namely (a) action-level deviations and (b) object-level deviations. Action-level deviations were those in which one or more expansive learning actions taken by the participants deviated from the dominant action planned by the interventionists for the given session. These deviations were typically surprises or disturbances that changed the course of the events for a limited period but did not change the overall object of learning; that is, after the deviation, the process returned to the plan. In object-level deviations the object and therefore also the course of the entire expansive learning process are qualitatively changed. Qualitative change does not necessarily imply rejection of the previously articulated object - it can also mean substantive expansion of the existing object.

One object-level deviation was found in the data. This was the emergence and evolution of pyramid models of clients and services that took place in sessions 7 and 8 . The intended function of session 7 was to summarize and stabilize a model of the new services the library would offer to research groups. The intended functions of session 8 were to sketch the implications of the new services for the internal organization of the library and to construct a plan for the implementation of the new model. What actually happened was that early in session 7, Librarian 2 questioned the sufficiency of tailor-made services for research groups and suggested that a qualitatively different model is needed, namely a pyramid depicting services ranging from standardized packages at the bottom to tailor-made specialized services at the top. The questioning and suggestion were endorsed and picked up by other participants. The discussion led to an assignment for session 8: The library staff would produce a new pyramid model depicting the range of services differentiated according to the degree of standardization $v s$. customization.

A third space (Gutiérrez, 2008) was opened for discussion and negotiation between the instructionally intended script proposing customized services and the counter-script initiated by Librarian 2 . The pyramid model specified in what kinds of services and for what kinds of clients customization and knotworking would be needed. Without the object-level deviation in the last two sessions of the CL, the entire process might have remained rather contained, sterile and possibly of little practical consequence. The object-level deviation led to a burst of modeling and examining actions that intensified and energized the process, indicating that the practitioners' transformative agency was starting to break out of the confines of the interventionists' instructional intentions.

\section{Generativity}

In the library CL, indications of generativity are thus far primarily observable in local continuity of the transformation efforts. In 2014, the campus libraries were merged and the university library was organized into three central service functions, one of which was devoted to research services. The former director of the City Center Campus Library became director of research services, and the information specialist who played a key role in the CL became an information specialist in the new research services. In follow-up interviews conducted in February and November 2015, these two key actors stated that now the 
organization was finally internally ready to focus on building and spreading strong knotworking relations and practices with research groups. At the level of domain appropriation, the project has generated numerous invitations from and exchanges with library communities in different parts of the world. At the level of method appropriation, a first full-scale analysis of a formative intervention applying the method of analysis of expansive learning actions developed in the library project has recently been completed by the interventionist research group of Bal (Bal \& al., 2015).

\section{CONCLUSIONS}

We have presented analyses of three formative interventions that allow us to answer the research questions posed at the beginning of this article:

1. In which ways were the objects of the activities practically transformed in the three formative interventions?

2. What methods of data analysis were developed and employed in the two CL cases and what do these methods yield in terms of moving forward our understanding of formative interventions?

3. What kinds of indications of the generative potential of formative interventions may be identified in the two CL cases?

Table 1 summarizes the findings of our inquiry. The inclusion of Case 1 allows a useful comparison with the two interventions involving outside researchers. The first six rows in Table $1\left(1^{\text {st }}\right.$ stimuli, conflict of motives, $2^{\text {nd }}$ stimuli, practical experimentation, germ cell, and ascending to the concrete) together contain answers to the first question. The first three rows contain findings concerning the principle of double stimulation. The next three rows contain findings related to the principle of ascending from the abstract to the concrete. The two bottom rows under the thick line in Table 1 (method of analysis and indications of generativity) contain answers to the second and third questions. The cells of the school in Brazil in these bottom rows are left empty, as this case serves the purpose of a contrasting example in our argument, rather than being a fully analyzed CL case. 
Table 1. Summary of findings from the analyses of the three interventions

\begin{tabular}{|c|c|c|c|}
\hline & $\begin{array}{l}\text { INTRAVENTION IN A FAVELA } \\
\text { SCHOOL }\end{array}$ & $\begin{array}{l}\text { CHANGE LABORATORY IN A } \\
\text { MIDDLE SCHOOL }\end{array}$ & $\begin{array}{l}\text { CHANGE LABORATORY IN AN } \\
\text { ACADEMIC LIBRARY }\end{array}$ \\
\hline $1^{\text {ST }}$ STIMULI & The flood and its consequences & $\begin{array}{l}\text { E.g., video of students spending } \\
\text { their recess sitting on the floor of } \\
\text { the school corridor }\end{array}$ & $\begin{array}{l}\text { E.g., video interview with librarian } \\
\text { worrying about the requirement to } \\
\text { become a substance specialist in a } \\
\text { branch of science }\end{array}$ \\
\hline $\begin{array}{l}\text { CONFLICT } \\
\text { OF MOTIVES }\end{array}$ & $\begin{array}{l}\text { Going to school at the risk of } \\
\text { getting sick versus staying home } \\
\text { and missing the opportunity to } \\
\text { learn and teach }\end{array}$ & $\begin{array}{l}\text { Should students be trusted or } \\
\text { controlled? }\end{array}$ & $\begin{array}{l}\text { Discipline-based specialization } \\
\text { versus generalist orientation; one- } \\
\text { way instruction versus collaboration } \\
\text { with clients }\end{array}$ \\
\hline $2^{\text {ND }}$ STIMULI & Educational management plan & $\begin{array}{l}\text { Three-phase vision of the school's } \\
\text { future }\end{array}$ & $\begin{array}{l}\text { The idea of knotworking and the } \\
\text { corresponding organization chart }\end{array}$ \\
\hline $\begin{array}{l}\text { PRACTICAL } \\
\text { EXPERIMENTATION }\end{array}$ & $\begin{array}{l}\text { Student relay, meetings in the } \\
\text { health care center, debates on } \\
\text { trash, making a film, discussing the } \\
\text { river in different school subjects }\end{array}$ & $\begin{array}{l}\text { Short-term improvements: E.g., } \\
\text { sofas placed in the aula of the } \\
\text { school, benches and computers in } \\
\text { the corridors }\end{array}$ & $\begin{array}{l}\text { E.g., developing a data management } \\
\text { guide together with the research } \\
\text { group of Cognitive Science }\end{array}$ \\
\hline GERM CELL & The manifesto My Stream, My Life & The Final Project & $\begin{array}{l}\text { Knotworking appropriated to meet } \\
\text { the needs of the library }\end{array}$ \\
\hline $\begin{array}{l}\text { THEORETICALLY } \\
\text { MASTERED } \\
\text { CONCRETE }\end{array}$ & $\begin{array}{l}\text { Human rights prize, petition for } \\
\text { building a park, project with the } \\
\text { councilman }\end{array}$ & $\begin{array}{l}\text { Rich diversity of topics in realized } \\
\text { Final Projects; teachers' positive talk } \\
\text { of students radically increased }\end{array}$ & $\begin{array}{l}\text { Knotworking implemented } \\
\text { primarily inside the library and } \\
\text { between campus libraries }\end{array}$ \\
\hline $\begin{array}{l}\text { METHOD OF } \\
\text { ANALYSIS }\end{array}$ & & $\begin{array}{l}\text { Longitudinal analysis of } \\
\text { categorization }\end{array}$ & $\begin{array}{l}\text { Analysis of expansive learning } \\
\text { actions and deviations from } \\
\text { instructional intentions }\end{array}$ \\
\hline $\begin{array}{l}\text { INDICATIONS OF } \\
\text { GENERATIVITY }\end{array}$ & & $\begin{array}{l}\text { New round of CL } 2000-01 \text {; school- } \\
\text { based CL in } 5 \text { countries; analysis of } \\
\text { categorization used as springboard } \\
\text { for analysis of agency }\end{array}$ & $\begin{array}{l}\text { Local continuity in the new library } \\
\text { organization 2014: preconditions for } \\
\text { knotworking with clients seen as } \\
\text { finally in place }\end{array}$ \\
\hline
\end{tabular}

In response to the first research question, in each one of the three interventions, learners expansively transformed the object of their activity. In the intravention in Brazil, the standard object of school instruction - students and the knowledge prescribed in the curriculum - was radically opened up. Students and school knowledge became embedded in the broader object of quality of life in the community, epitomized by the river and the trash. In the middle school CL, the expansion of the object was focused on the students: apathetic students were reconceptualized as capable and potentially competent. This expanded view of students was epitomized in the students' possibility to raise their grades by producing a competent Final Project. In the university library CL, the anonymous researchers as recipients of routine services and associated instructions were reconceptualized as collaboration partners in need of complex, jointly designed services. This expansion was epitomized in the successful effort to make research services a fully acknowledged and supported key function of the library.

Formative interventions are expansive learning processes in which learners willfully reconceptualize and practically transform the object of their activity to face its unsustainable historically formed contradictions. When researcher-interventionists are involved, as in the two CL cases, they can provoke and support the expansion of the object of the learners' activity by mobilizing concepts and principles stemming from cultural-historical activity theory. The CL facilitates the translation of these concepts and principles into mediating instruments constructed and employed throughout the process toward innovative solutions. It seems that in the case of the school in Brazil the contradictions were mature enough to allow for the initiative by the leading pedagogical coordinator to mobilize the community in an expansive learning process. The flood and its consequences were such a pressing first stimulus that double stimulation and ascending to the concrete emerged as if spontaneously. In the two CL cases expansive learning was provoked and supported by the researcher- 
interventionists. Double stimulation and ascending from the abstract to the concrete emerged in interplay between instructional initiatives of the researcher-interventionists and initiatives from the practitioners. For instance, documented evidence and examples of recurring problems and disturbances in the practitioners' activity were presented by the researcherinterventionists and served as effective first stimuli. The second stimulus, for instance the idea of knotworking in the library brought in by the researcher-interventionists, was shaped and filled with meaning by the practitioners and reformulated as their own organization chart.

Our second question concerns the methods of analysis developed to examine CL processes. We have discussed, only two such methods, namely the longitudinal categorization analysis and the analysis of expansive learning actions and deviations from instructional intentions. Other methods developed specifically to analyze entire CL processes include the analysis of discursive manifestations of contradictions (Engeström \& Sannino, 2011) and the analysis of expressions of transformative agency (Haapasaari, Engeström \& Kerosuo, 2014; Vänninen, Pereira-Querol \& Engeström, 2015).

The two methods for analyzing change associated with the CLs presented in this article serve very different functions. The longitudinal categorization analysis is primarily a means to identify pervasive changes in the ways a community talks about and categorizes its object. In its focus on collective meanings, it comes close to Moscovici's (1984) analyses of social representations, Marton's (1984) phenomenography, and Zerubavel's (1999) mindscapes. However, our method differs from these approaches in its focus on local change over time. Indeed, we see longitudinal analysis of categorizations as a method of investigating collective outcomes of learning in communities.

Obviously the simple dichotomy of positive versus negative talk used in the analysis of Jakomäki data is merely a beginning; more nuanced analyses are in the making in CL projects in different parts of the world. The analysis revealed the important phenomenon of expansion through enrichment, which is a gradual process that does not happen as an abrupt once-and-for-all change. The teachers shifted from predominantly negative to predominantly positive categorization of students, but they did this without eliminating or diminishing their older ways of talking - the new, positive ways of talking took over without suppressing the old ones. We see this kind of expansion, at least potentially, as a move toward more flexible and less static discourse and thinking among the teachers.

The method of analyzing expansive learning actions and deviations from instructional intentions serves the function of gaining an understanding of the dynamics of the expansive learning process unfolding in the CL intervention. Because the CL is a planned process, one may ask why one should investigate actions that are required and elicited by the plan in any case. As we have argued elsewhere (Engeström \& Sannino, 2012), relying on the work of Kruger and Tomasello (1998), most human learning is instructed learning in the broad sense of the word, but instruction and learning never smoothly correspond to one another. Therefore, we need to look at instruction and learning - the plans and actions of instructors as well as the actions of learners - as dialectically intertwined. This means that the prescribed and planned process the instructor is trying to implement must be compared and contrasted with the actual process performed by the learners. The two will never fully coincide. The gap, struggle, negotiation and occasional merger between the two need to be 
taken as key resources for understanding processes of learning in which the formation of agency is a key quality.

The analysis of the learning actions in the library CL revealed three important features of expansive learning in formative interventions. First, the expansive learning actions occur along and interspersed with non-expansive actions. Second, the expansive actions do not occur in the theoretically prescribed order; there are iterations and digressions. However the overall picture corresponds to the general sequence of ascending from the abstract to the concrete. Third, an object-level deviation triggered a smaller iterative cycle within the overall process of expansive learning, resulting in a nested cyclic pattern. These findings will serve as the basis for comparisons with expansive learning processes in other formative interventions. Such comparisons may eventually lead to an understanding of different types of expansive learning processes, their preconditions and consequences.

Our third question concerns possible indications of generativity in the two CLs. In the middle school case, we identified indications of all three kinds of generativity: local continuity, domain appropriation, and method appropriation. In the library case, we identified indications of local continuity, and initial indications of domain appropriation and method appropriation. A relatively short period of time has lapsed after the formal termination of the CL intervention in the library. Domain appropriation and method appropriation seem to have long incubation times. The Jakomäki CL was conducted in 199899; the next CLs in the domain of formal schooling were reported in research articles about 10 years later. A similar hiatus is observable in method appropriation with regard to longitudinal analysis of categorizations initially applied in the Jakomäki case. Such a lengthy hiatus is a challenge to research. Meeting this challenge is rewarding, as it may enrich our understanding of learning as a temporally and socio-spatially distributed process that can be enhanced with theoretically well-grounded interventions.

How do formative interventions such as the ones discussed above differ from design-based research in the learning sciences tradition? An activity-theoretical formative intervention approach is distinctive in three ways: 1) formative interventions are based on design done by the learners; 2) the collective design effort is seen as part of an expansive learning process, including participatory analyses ${ }^{5}$ and implementation phases; 3 ) rather than aiming at transferable and scalable solutions (Clarke \& Dede, 2009; Fishman \& al., 2004), formative interventions aim at generative solutions developing over comparatively lengthy periods of time in both the researched activities and in the research community.

As we have shown, in formative interventions learners produce their own collective designs as an expansive learning process that often confronts and deviates from researcherinterventionists' instructional intentions. In the Jakomäki middle school, the CL intervention included an important object-level deviation from the plan designed by the responsible teachers and endorsed by the researcher-interventionists, namely the successful initiative of

\footnotetext{
${ }^{5}$ By participatory analyses we refer to analyses of contradictions in the activity conducted by the participants during and between the CL intervention sessions. These analyses should not be confused with the analyses conducted by the researcher-interventionists after the completion of the intervention (such as the longitudinal categorization analysis and the analysis of expansive learning actions reported in this article).
} 
the teachers of immigrant students to include also their students in the Final Project. In the university library, there was also an object-level deviation, namely the successful initiative of a librarian to expand the design beyond tailor-made services for research groups to include also standardized services in a pyramid-shaped model. This was a deviation from the instructional intention of the researcher-interventionists, who expected the process to move on with finalizing and implementing a model of tailor-made knotworking services for research groups. In both cases, the deviations were manifestations of transformative agency among the participants within expansive learning. Basically, the learners took over the direction and scope of the expansive learning process, redefining and expanding its object. Deviations and surprises such as these are at the core of expansive learning in formative interventions. These interventions generate solutions that are not known ahead of time and not under the control of the researchers.

There was evidence of generativity in the Brazilian favela as well, where the process rapidly expanded beyond the school and encompassed the entire community, including the health care center. In Jakomäki, the intervention in 1998-99 was contained within the school; the process opened up beyond the school only in a second CL in 2000-01 (Engeström, Engeström \& Suntio, 2002b). In the third case, the process was centered in the library but included from the beginning four research groups that represented the clients of the library. These variations in the ownership of the process and heterogeneity of participants' involvement represent a challenge for future research.

CL formative interventions regard the collective design effort as a phase in an expansive learning process. Design emerges out of collective analyses of the historical contradictions, current disturbances and possible alternative futures of the activity in question. And if design is to ascend to the concrete, it must lead to generative outputs in the form of material implementations. In other words, CLs' ultimate ambition is to carry out collaborative inquiries that lead to germ cells of new, expanded forms of activity.

Each of the three cases demonstrates the longitudinal, open-ended and generative character of formative interventions. Even though a CL intervention necessarily has a finite number of sessions and its systematic follow-up has a finite duration, these formal end points do not mark completion or closure. This poses a challenge to researchers: When - if ever - can we talk about durable changes? Activities are continuously in transition, so stability is a momentary state rather than a permanent outcome. In our theoretical perspective, this challenge requires focusing on two aspects of expansive learning: its agentive character and its materiality. The former means that formative interventions generate outcomes that are authored and owned by the participants. The second aspect, materiality, means that the outcomes of formative interventions are not merely cognitive and mental, but publicly externalized concepts and materially grounded novel forms of activity that can act as "ratchets" (Tomasello, 1999) for further generative developments. These outcomes concern both tangible developments in the participants' activity and the equally tangible conception of new methods of analysis as research outputs.

\section{ACKNOWLEDGMENTS}

We thank the reviewers of our manuscript and the editors for their insightful comments and suggestions. We welcomed Michael Cole's suggestion of the notion of intravention. We are particularly grateful to the participants in the formative interventions discussed in the paper 
for their time and collaboration.

\section{FUNDING}

The writing of this article was supported by an Academy Research Fellowship (No. 292730) granted to Annalisa Sannino by the Academy of Finland, Research Council for Culture and Society. The research reported here has been also funded by the Academy of Finland through the project "Concept Formation and Volition in Collaborative Work" (No.253804, PI Yrjö Engeström), the project "Learning in Productive Social Movements" (No. 274244, PI Yrjö Engeström) and a CIMO scholarship (TM-12-8554) to Monica Lemos.

\section{REFERENCES}

Argyris, C. (1980). Inner contradictions of rigorous research. New York: Academic Press.

Bal, A., Schrader, E. M., Afacan, K., Olsen, R., Cakir, H. \& Mawene, D. (2015). Culturally responsive positive behavior interventions and supports: Implementing Learning Lab at a high school for systemic transformation. Manuscript submitted for publication.

Brown, A. L. (1992). Design experiments: Theoretical and methodological challenges in creating complex interventions in classroom settings. The Journal of the Learning Sciences, 2(2), 141-178.

Carmen, R. \& Sobrado, M. (2000). A future for the excluded. London: Zen Books.

Clarke, J., \& Dede, C. (2009). Design for scalability: A case study of the River City curriculum. Journal of Science Education and Technology, 18(4), 353-365.

Clot, Y. (2009). Clinic of Activity: The dialogue as instrument. In A. Sannino, H. Daniels \& K. Gutiérrez (Eds.), Learning and expanding with activity theory (pp. 286-302). Cambridge: Cambridge University Press.

Davydov, V. V. (1990). Types of generalization in instruction: Logical and psychological problems in the structuring of school curricula. Reston, VA: National Council of Teachers of Mathematics.

Davydov, V. V. (2008). Problems of developmental instruction: A theoretical and experimental psychological study. Hauppauge, NY: Nova Science Publishers.

Engeström, Y. (2011). From design experiments to formative interventions. Theory and Psychology, 21(4), 598-628.

Engeström, Y. (2013). Collective concept formation as creation at work. In A. Sannino \& V. Ellis (Eds.), Learning and collective creativity: Activity-theoretical and sociocultural studies (pp. 234-257). New York: Routledge.

Engeström, Y. (2015). Learning by expanding: An activity-theoretical approach to developmental research. $2^{\text {nd }}$ edition. Cambridge: Cambridge University Press.

Engeström, Y., Engeström, R. \& Suntio, A. (2002a). Can a school community learn to master its own future? An activity-theoretical study of expansive learning among middle school teachers. In G. Wells \& G. Claxton (Eds.) Learning for life in the $21^{\text {st }}$ century: Sociocultural perspectives on the future of education. London: Blackwell.

Engeström, Y., Engeström, R. \& Suntio, A. (2002b). From paralyzing myths to expansive action: Building computer-supported knowledge work into the curriculum from below. In G. Stahl (Ed.), Computer support for collaborative learning: Foundations for a CSCL community. Hillsdale: Lawrence Erlbaum.

Engeström, Y., Engeström, R., \& Vähäaho, T. (1999). When the center does not hold: The importance of knotworking. In S. Chaiklin, M. Hedegaard, \& U. J. Jensen (Eds.), 
Activity theory and social practice: Cultural-historical approaches (pp. 345-374). Aarhus, Denmark: Aarhus University Press.

Engeström, Y., Nummijoki, J. \& Sannino, A. (2012). Embodied germ cell at work: Building an expansive concept of physical mobility in home care. Mind, Culture, and Activity, 19(3), 287-309.

Engeström, Y., Rantavuori, J. \& Kerosuo, H. (2013). Expansive learning in a library: Actions, cycles and deviations from instruction intentions. Vocations and Learning, 6(1), 81-106.

Engeström, Y. \& Sannino, A. (2010). Studies of expansive learning: Foundations, findings and future challenges. Educational Research Review, 5, 1-24.

Engeström, Y. \& Sannino, A. (2011). Discursive manifestations of contradictions in organizational change efforts: A methodological framework. Journal of Organizational Change Management, 24(3), 368-387.

Engeström, Y. \& Sannino, A. (2012). Whatever happened to process theories of learning? Learning, Culture and Social Interaction, 1(1), 45-56.

Engeström, Y., Virkkunen, J., Helle, M., Pihlaja, J. \& Poikela, R. (1996). Change laboratory as a tool for transforming work. Lifelong Learning in Europe, 1(2), 10-17.

Fishman, B., Marx, R. W., Blumenfeld, P., Krajcik, J., \& Soloway, E. (2004). Creating a framework for research on systemic technology innovations. The Journal of the Learning Sciences, 13(1), 43-76.

Flyvbjerg, B. (2001). Making social science matter: Why social inquiry fails and how it can succeed again. Cambridge: Cambridge University Press.

Gorski, P. C. (2011). Unlearning deficit ideology and the scornful gaze: Thoughts on authenticating the class discourse in education. Counterpoints, 402, 152-173.

Greeno, J. G. (1989). Situations, mental models, and generative knowledge. In D. Klahr \& K. Kotovsky (Eds.), Complex information processing: The impact of Herbert A. Simon (pp. 285-318). Hillsdale, NJ: Lawrence Erlbaum.

Gutiérrez, K. D. (2008). Developing a sociocritical literacy in the third space. Reading Research Quarterly, 43(2), 148-164.

Gutiérrez, K. D. \& Penuel, W. (2014). Relevance to practice as a criterion for rigor. Educational Researcher, 43(1), 19-23.

Haapasaari, A., Engeström, Y., \& Kerosuo, H. (2014). The emergence of learners' transformative agency in a Change Laboratory intervention. Journal of Education and Work. DOI: 10.1080/13639080.2014.900168

Hester, S. \& Eglin, P. (1997). Culture in action: Studies in membership categorization analysis. Washington, DC: University Press of America.

Horn, I. S. (2007). Fast kids, slow kids, lazy kids: Framing the mismatch problem in mathematics teachers' conversations. The Journal of the Learning Sciences, 16(1), 37-79.

Ilyenkov, E. V. (1982). The dialectics of the abstract and the concrete in Marx's Capital. Moscow: Progress.

Jussim, L. \& Harber, K. D. (2005). Teacher expectations and self-fulfilling prophecies: Knowns and unknowns, resolved and unresolved controversies. Personality and Social Psychology Review, 9(2), 131-155.

Kruger, A. C., \& Tomasello, M. (1998). Cultural learning and learning culture. In D. R. Olson, \& N. Torrance (Eds.), The handbook of education and human development (pp. 369-387). Malden: Blackwell. 
Lapshin, Y., Ivanova, A. \& Chernish, A. (2015). Developing agentive subjects in school: A Russian case study of educational change from below. In B. Selau \& R. F. de Castro (Eds.), Cultural-historical approach: Educational research in different contexts ( $p$. 173-192). Porto Alegre: Edipucrs.

Lehman, P. (1999). Economic policy: Trash as a commodity. Journal of Management History, 5(3), 120-137.

Leont'ev, A. N. (1978). Activity, consciousness and personality. Englewood Cliffs: Prentice-Hall.

Lepper, G. (2000). Categories in text and talk. London: Sage.

Liberali, F. (2012). Gestao escolar em cadeias criativas [School management in creative chains]. Brasilia: Conselho Nacional de Desenvolvimento Cientifico e Tecnológico (in Portuguese).

Lincoln, Y. S. \& Guba, E. G. (1985). Naturalistic inquiry. Newbury Park: Sage.

Lindsey, R. B., Karns, M. S., \& Myatt, K. (2010). Culturally proficient education: An assetbased response to conditions of poverty. Corwin Press.

Marton, F. (1984). Towards a psychology beyond the individual. In K. M. J. Lagerspetz \& P. Niemi (Eds.), Psychology in the 1990s. Amsterdam: North-Holland (p. 45-72)

Maxwell, J. A. (2005). Qualitative research design: An interactive approach. $2^{\text {nd }}$ Edition. Thousand Oaks: Sage.

Moscovici, S. (1984). The phenomenon of social representations. In R. M. Farr \& S. Moscovici (Eds.), Social representations. Cambridge: Cambridge University Press.

Naghieh, A., Thompson, M. \& Montgomery, P. (2014). A system level intervention to address teacher stress: Qualitative evidence from a pilot study of the Change Laboratory methodology in UK secondary schools. Paper presented at the EGOS colloquium, Rotterdam, July 2014.

Rainio, A. P. \& Hofmann, R. (2015). Transformations in teachers' discourse about their students during a school-led pedagogic intervention. The European Journal of Social and Behavioural Sciences, 13, 1815-1829.

Rosenthal, R., \& Jacobson, L. (1968). Pygmalion in the classroom. New York: Holt, Rinehart \& Winston.

Sannino, A. (2008). From talk to action: Experiencing interlocution in developmental interventions. Mind, Culture, and Activity, 15(3), 234-257.

Sannino, A. (2010a). Breaking out of a professional abstraction: The pupil as materialized object for trainee teachers. In V. Ellis, A. Edwards \& P. Smagorinsky (Eds.), Culturalhistorical perspectives on teacher education and development. New York: Routledge ( $\mathrm{p}$. 146-159).

Sannino, A. (2010b). Teachers' talk of experiencing: Conflict, resistance and agency. Teaching and Teacher Education, 26(4), 838-844.

Sannino, A. (2011). Activity theory as an activist and interventionist theory. Theory and Psychology, 21(5), 571-597.

Sannino, A. (2015). The principle of double stimulation: A path to volitional action. Learning, Culture, and Social Interaction, 6, 1-15.

Schmittau, J. \& Morris, A. (2004). The development of algebra in the elementary mathematics curriculum of V.V. Davydov. The Mathematics Educator, 8(1), 60 - 87.

Stokoe, E. (2012). Moving forward with membership categorization analysis: Methods for systematic analysis. Discourse Studies, 14(3), 277-303. 
Teräs, M. \& Lasonen, J. (2013). The development of teachers' intercultural competence using a Change Laboratory method. Vocations and Learning, 6, 107-134.

Tomasello, M. (1999). The cultural origins of human cognition. Cambridge, MA: Harvard University Press.

Valencia, R. R. (Ed.). (2012). The evolution of deficit thinking: Educational thought and practice. New York: Routledge.

Vänninen, I., Pereira-Querol, M., \& Engeström, Y. (2015). Generating transformative agency among horticultural producers: An activity-theoretical approach to transforming Integrated Pest Management. Agricultural Systems, 139, 38-49.

Virkkunen, J. \& Newnham, D. S. (2013). The Change Laboratory: A tool for collaborative development of work and education. Rotterdam: Sense.

Virkkunen, J., Newnham, D. S., Nleya, P. \& Engeström, R. (2012). Breaking the vicious circle of categorizing students in school. Learning, Culture and Social Interaction, 1(2), 183-192.

Virkkunen, J. \& Tenhunen, E. (2010). Finding a concept that integrates specialists' knowhow: The case of special school for handicapped and neurologically ill children. Actio, 3, $1-23$.

Vygotsky, L. S. (1987). The collected works of L. S. Vygotsky: Vol. 1. Problems of general psychology. New York: Plenum.

Vygotsky, L. S. (1997). The collected works of L. S. Vygotsky: Vol. 4. The history of the development of higher mental functions. New York: Plenum.

Wittrock, M. C. (1974). Learning as a generative process 1. Educational psychologist, 11(2), 87-95.

World Bank (2012). Finland: School autonomy and accountability. Systems Approach for Better Education Results (SABER) country report. Washington DC : World Bank.

Zerubavel, E. (1999). Social mindscapes: An invitation to cognitive sociology. Cambridge, MA: Harvard University Press. 